\title{
Penerapan teknik faded examples untuk meningkatkan kemampuan pemecahan masalah materi pengayaan trigonometri SMA
}

\author{
Hanifa Prahastami Pambayun ${ }^{1}$, Endah Retnowati ${ }^{1}$ * \\ ${ }^{1}$ Department of Mathematics Education, Program Pascasarjana, Universitas Negeri Yogyakarta. \\ Jalan Colombo No. 1, Karangmalang, Yogyakarta, 55281, Indonesia \\ * Corresponding Author. Email: e.retno @uny.ac.id \\ Received: 8 March 2018; Revised: 23 April 2018; Accepted: 27 April 2018
}

\begin{abstract}
Abstrak
Penelitian ini bertujuan untuk menghasilkan dan mendeskripsikan pengembangan bahan ajar pengayaan trigonometri SMA menggunakan teknik faded examples yang berkualitas untuk meningkatkan kemampuan pemecahan masalah siswa. Kualitas bahan ajar yang dikembangkan mencakup aspek kevalidan, keefektifan, dan kepraktisan. Penelitian ini merupakan penelitian pengembangan dengan model Plomp yang mencakup tiga tahapan. (1) penelitian awal mencakup analisis kebutuhan dan analisis konteks, (2) pengembangan yang mencakup desain produk dan pembuatan produk, dan (3) evaluasi yang meliputi proses validasi dan proses implementasi. Proses pengembangan melibatkan dua ahli, satu orang guru dan 50 siswa (siswa kelas $X$ pengayaan 1 dan $X$ pengayaan 2) SMA IPA di Mataram. Hasil dari penelitian ini adalah bahan ajar pengayaan berupa buku guru dan buku siswa yang dikembangkan dengan menerapkan teknik faded examples. Pada buku pengayaan terdapat paket faded examples dengan jenis backward dan forward fading dimana pada akhir paket, siswa diminta untuk membuat sendiri soal sesuai dengan materi yang sedang dipelajari. Teknik ini dikembangkan oleh teori desain pembelajaran bernama Cognitive Load Theory (CLT). Hasil penelitian menunjukkan bahwa bahan ajar ini layak digunakan karena dinilai sangat baik secara isi dan penyajian oleh dosen validator, praktis oleh guru matematika dan praktis digunakan oleh siswa. Hasil ketuntasan belajar adalah sebanyak $100 \%$ siswa mencapai nilai minimal kemampuan pemecahan masalah.
\end{abstract}

Kata Kunci: bahan ajar, faded examples, cognitive load, kemampuan pemecahan masalah.

\section{The application of faded examples techniques to improve student's problem solving ability on trigonometry at high school level}

\begin{abstract}
This study was aimed to produce and describe the quality of the developed Trigonometric Senior High School Science Program Enrichment's Instructional Materials using Faded-Examples Techniques to Improve Problem Solving Ability. The quality of the developed teaching materials include all aspects of validity, effectiveness, and practicality. This was a developmental research used three phases Plomp's model which consists of: (1) preliminary studies which involved the needs and context analysis, (2) product design development, and (3) the evaluation process of product validation and implementation. The development process involves two experts as validator, one teacher, and 50 students ( $X$ pengayaan 1 and $X$ pengayaan 2 ). The study results the trigonometric enrichment's teaching materials which consists of the teacher's textbook and the student's textbook that was developed using the faded-examples technique. This technique based on The Cognitive Load Theory (CLT) instructional design. The results of the study showed that the quality of the developed trigonometric enrichment's teaching materials is "very good" according to lecturer validation and "practical" according to the evaluation from the teachers and students. The results of the learning showed that 100\% of the students passed the minimum grade criteria of problem solving skills.
\end{abstract}

Keywords: teaching materials, faded examples, cognitive load, problem solving ability.

How to Cite: Pambayun, H., \& Retnowati, E. (2018). Penerapan teknik faded examples untuk meningkatkan kemampuan pemecahan masalah materi pengayaan trigonometri SMA. Jurnal Riset Pendidikan Matematika, 5(1), 73-81. doi:http://dx.doi.org/10.21831/jrpm.v5i1.12149

Permalink/DOI: http://dx.doi.org/10.21831/jrpm.v5i1.12149 


\section{Jurnal Riset Pendidikan Matematika, 5 (1), 2018 - 74}

Hanifa Prahastami Pambayun, Endah Retnowati

\section{PENDAHULUAN}

Matematika merupakan salah satu mata pelajaran wajib sejak tingkat sekolah dasar sampai menengah atas. Matematika menurut Fennema \& Romberg (1999, p. 5) adalah aktivitas manusia yang merefleksikan pekerjaan matematika. Matematika sekolah memiliki karakteristik tersendiri seperti yang telah disebutkan dalam Permendikbud RI Nomor 59 tahun 2014 bahwa karakteristik matematika sekolah berbeda dengan pelajaran lain karena memiliki: (1) penyajian; (2) pola pikir; (3) keterbatasan semesta; dan (4) tingkat keabstrakan tertentu. Karakteristik matematika sekolah sangat penting untuk diperhatikan guru selama proses pembelajaran agar tujuan belajar dapat tercapai.

Nitko \& Brookhart (2011, p. 18) menyatakan bahwa pembelajaran merupakan suatu proses dimana guru menyediakan suatu kondisi yang dapat membantu siswa mencapai targettarget belajar. Tujuan pembelajaran dalam matematika dapat tercapai jika pembelajaran matematika berlangsung dengan efektif. Hal ini didukung oleh pernyataan National Council of Teacher of Mathematics (NCTM) yang menyatakan bahwa pembelajaran matematika yang efektif akan dapat menumbuhkan pemahaman tentang apa yang siswa pelajari (National Council of Teacher Mathematics, 2000, p. 16). Proses pembelajaran dapat berlangsung efektif bila didukung dengan penggunaan bahan ajar yang sesuai dengan kebutuhan siswa. Penggunaan bahan ajar merupakan salah satu fasilitas yang diterima siswa selama proses pembelajaran berlangsung agar tujuan belajar dapat dicapai secara maksimal.

Pembelajaran yang efektif dapat dilihat dari prestasi belajar siswa yang memuaskan. Newby, Lehman, Russel, \& Stepich (2000, p. 117) menyatakan bahwa prestasi adalah salah satu indikator hasil belajar yang baik. Salah satu faktor yang dapat mempengaruhi prestasi belajar siswa adalah kemampuan pemecahan masalah siswa. Kemampuan pemecahan masalah menurut Khomsiatun \& Retnawati (2015, p. 106) adalah suatu kemampuan dalam menyelesaikan masalah dengan memahami terlebih dahulu masalah yang dihadapi sehingga dapat menentukan jenis masalah dan solusi apa yang tepat untuk menyelesaikannya.

Adapun cara yang dapat dilakukan siswa dalam meningkatkan kemampuan pemecahan masalah yaitu dengan pendalaman materi dan latihan terbimbing terkait soal-soal pemecahan masalah. Salah satu kegiatan yang diharapkan mampu menjadi wadah bagi siswa untuk dapat memahami lebih mendalam materi pelajaran yang telah dipelajari dan dapat meningkatkan kemampuan pemecahan masalah adalah program pengayaan.

Pembelajaran pengayaan menurut Departemen Pendidikan Nasional (2008, p. 3) merupakan pembelajaran tambahan dengan tujuan untuk memberikan kesempatan belajar bagi peserta didik khususnya yang memiliki kelebihan sehingga mereka dapat mengoptimalkan perkembangan minat, bakat, dan kecakapannya. Pengayaan ini dimaksudkan untuk meningkatkan dan mempertahankan hasil belajar yang diperoleh siswa, serta sebagai salah satu upaya untuk mengembangkan potensi siswa secara optimal. Seperti yang tertera dalam Depdiknas tahun 2008 tentang panduan penyelenggaraan pengayaan, salah satu jenis pembelajaran pengayaan adalah pembelajaran dengan menggunakan materi-materi pemecahan masalah yang diberikan kepada siswa yang siap secara kognitif (Departemen Pendidikan Nasional, 2008).

Ruang lingkup materi matematika SMA sesuai dengan Permendikbud Nomor 59 tahun 2014 terdiri dari (1) Bilangan, (2) Aljabar, (3) Geometri, (4) Trigonometri, (5) Statistika dan Peluang, (6) Logika matematika, dan (7) Kalkulus. Dari ketujuh ruang lingkup materi ini, trigonometri dan kalkulus dapat dikatakan sebagai materi yang baru karena belum dipelajari di SMP. Materi trigonometri lebih banyak bersifat abstrak khususnya pada bagian pembuktian bentuk-bentuk trigonometri sehingga dapat dikatakan sebagai materi yang cukup sulit dipelajari. Sebagian besar siswa kesulitan menerapkan rumus perbandingan trigonometri pada soal-soal yang diberikan (Ahmad, 2015, p. 298).

Bahan ajar merupakan seperangkat sarana pembelajaran yang memuat materi pembelajaran, metode, batasan-batasan, dan cara mengevaluasi yang didesain secara sistematik dan menarik untuk mencapai tujuan pembelajaran (Widodo \& Jasmadi, 2008, p. 40). Selain mempengaruhi hasil belajar siswa, bahan ajar yang digunakan di sekolah juga dapat mempengaruhi kemampuan pemecahan masalah. Hal ini disebabkan karena bahan ajar memuat materi dan kompetensi yang diperoleh siswa saat pembelajaran berlangsung (Prastowo, 2011, p. 66). Dalam penelitian ini, bahan ajar yang akan dikembangkan berupa buku yang terdiri dari buku guru dan buku siswa. Menurut Majid 
(2008, p. 175) buku merupakan bahan tertulis yang menyajikan ilmu pengetahuan yang merupakan buah pikiran dari pengarangnya.

Pengembangan bahan ajar yang baik dilakukan dengan memperhatikan kemampuan awal siswa (Sweller, Ayres, \& Kalyuga, 2011). Adanya perbedaan pengetahuan awal siswa menyebabkan tidak semua model pembelajaran efektif diterapkan pada seluruh siswa di kelas. Menurut Kalyuga (2008), teknik pembelajaran yang efektif untuk pelajar pemula dapat menjadi tidak efektif untuk pelajar yang lebih berpengalaman, begitupula sebaliknya.

Pengetahuan awal yang dimiliki siswa merupakan modal dasar terjadinya proses pembelajaran yang efektif sesuai dengan kemampuannya. Seperti halnya Sweller, Kalyuga (2008) juga berpendapat bahwa pembelajaran akan menjadi efektif jika pembelajaran tersebut dapat memudahkan siswa untuk menerima materi pelajaran dan disesuaikan dengan kemampuannya. Menurut Kalyuga (2008), siswa dengan pengetahuan awal tinggi dapat belajar melalui implicitly guided instruction, tetapi sebaliknya, siswa dengan kemampuan awal rendah memerlukan explicitly guided instruction. Menurut Renkl, Atkinson, \& Große (2004), transisi dari belajar dengan explicit guidance ke implicit guidance dapat diperhalus dengan memberikan faded-worked examples. Renkl et al. (2004) mengkaji bahwa teknik fading ini telah diteliti dan terbukti efektif terutama untuk siswa dengan kemampuan matematis yang rendah. Teknik faded examples didasari oleh teori pembelajran bernama cognitive load theory.

Cognitive load theory merupakan teori pembelajaran yang terbukti menghasilkan lingkungan pembelajaran yang efisien sebagai konsekuensi dari memanfaatkan proses kognitif manusia (Clark, Nguyen, \& Sweller, 2011, p. 1). Terdapat dua tipe utama pada cognitive load yaitu intrinsic load dan extraneous load. Renkl et al. (2004) menjelaskan bahwa intrinsic load merupakan kekompleksan materi pembelajaran yang bergantung pada tingkat pengetahuan awal siswa. Extraneous load disebabkan oleh aktivitas kognitif selama pembelajaran berlangsung yang tidak berkontribusi secara langsung. Muatan kognitif ini diakibatkan oleh penyajian materi pembelajaran.

Menurut Retnowati (2016), contoh yang efektif dapat dibentuk berdasarkan prinsip yang dikembangkan dengan cognitive load theory. Prinsip-prinsip tersebut menjelaskan bagaimana memodifikasi format dari example yang didasar- kan pada petunjuk untuk meningkatkan atau menurunkan extraneous maupun intrinsic cognitive load. Adapun prinsip pertama menurut Retnowati adalah dengan mereduksi extraneous cognitive load. Prinsip kedua yaitu memanajemen intrinsic cognitive load. Dan yang terakhir adalah meningkatkan germanecognitive load. Prinsip-prinsip ini terutama diterapkan pada bahan ajar yang baru atau kompleks karena bahan ajar yang sederhana atau sudah dikenal dengan baik oleh siswa biasanya mudah dipelajari meskipun penyajiannya kurang baik.

Teknik faded examples dalam pengembangan bahan ajar untuk materi pengayaan ini mengacu pada prinsip-prinsip pengembangan bahan ajar dalam cognitive load theory. Teknik ini dipertimbangkan dapat memfasilitasi siswa yang memiliki pengetahuan awal yang belum cukup kuat sehingga siswa dapat belajar dengan lebih mudah.

Teknik fading yang terdapat dalam faded examples merupakan teknik pengembangan materi dalam bahan ajar dimana dalam pembelajaran siswa melengkapi solusi problem solving yang diberikan. Soal-soal pengayaan biasanya adalah soal yang agak sulit atau lebih sulit dari biasanya dan memerlukan beberapa langkah penyelesaian. Teknik fading memfasilitasi siswa dengan latihan dimana sebagian cara menyelesaikan soal ditunjukkan dan sebagian lagi siswa yang melengkapi. Melalui teknik ini (Renkl et al., 2004; Sweller et al., 2011), siswa diberi latihan-latihan soal pengayaan dengan mengisi langkah penyelesaian yang kosong bertahap. Sampai siswa paham dan lancar, siswa diberi latihan soal tanpa ada contoh penyelesaian untuk materi selanjutnya.

Pengembangan bahan ajar dengan faded examples dilakukan dengan memperhatikan tingkat pengetahuan awal siswa sehingga dapat menjadi wadah untuk mengembangkan keterampilan siswa dalam pemecahan masalah matematika. Oleh karena itu, tujuan penelitian ini adalah untuk mengembangkan bahan ajar pengayaan khususnya pada materi trigonometri SMA dengan menggunakan model faded examples untuk meningkatkan kemampuan pemecahan masalah matematika siswa. Manfaat pelaksanaan penelitian pengembangan ini adalah (1) tersedianya bahan ajar pengayaan trigonometri SMA menggunakan teknik faded examples yang layak digunakan ditinjau dari aspek kevalidan, kepraktisan, dan keefektifan, serta (2) guru dan siswa dapat menggunakan bahan ajar pengayaan trigonometri SMA menggunakan teknik yang 


\section{Jurnal Riset Pendidikan Matematika, 5 (1), 2018 - 76}

Hanifa Prahastami Pambayun, Endah Retnowati

dikembangkan sebagai sumber belajar matematika yang berkualitas.

\section{METODE}

Penelitian ini merupakan penelitian pengembangan bahan ajar. Jenis penelitian ini adalah penelitian desain (design research) yang menggunakan model Plomp (2013, p. 19) sebagai model penelitian. Penelitian ini merupakan penelitian dengan paradigm mixed method (Creswell, 2015, p. 535), dengan embedded design yang difokuskan pada pengembangan produk berupa bahan ajar untuk materi pengayaan Trigonometri SMA IPA dengan menggunakan model faded examples.

Uji coba produk dilaksanakan pada bulan April-Mei 2016 di SMAN 5 Mataram, Lombok, Nusa Tenggara Barat. SMAN 5 Mataram dipilih karena merupakan SMA yang memiliki nilai rata-rata UN yang cukup tinggi pada materi trigonometri sehingga dianggap cocok sebagai tempat uji coba untuk penerapan bahan ajar pengayaan materi trigonometri SMA.

Subjek uji coba dalam penelitian ini adalah 50 siswa kelas X SMAN 5 Mataram Tahun Ajaran 2015/ 2016 sebanyak 2 kelas yaitu kelas $\mathrm{X}$ pengayaan 1 dan $\mathrm{X}$ pengayaan 2 . Penelitian ini menggunakan dua kelas sebagai kelas penelitian karena keterbatasan waktu penelitian sehingga setiap kelas mempelajari materi pada bab yang berbeda. Adapun siswa yang dipilih dalam uji coba merupakan siswa kelas $\mathrm{X}$ yang memiliki nilai trigonometri yang telah memenuhi KKM.

Model pengembangan bahan ajar yang digunakan dalam penelitian diadopsi dari model Plomp \& Nieveen (2007, p. 15) dengan langkahlangkah sebagai berikut: (1) Tahap penelitian awal yaitu tahap pra-perencanaan pengembangan produk berupa bahan ajar. Pada tahap ini peneliti menganalisis hal-hal yang berkaitan dengan pengembangan bahan ajar antara lain: analisis konteks berupa analisis kebutuhan dan analisis situasi, tinjauan literatur, dan pengembangan kerangka konseptual; (2) prototyping phase, yang bertujuan untuk mengembangkan produk bahan ajar yang disesuaikan dengan kebutuhan siswa; (3) assessment phase, bertujuan untuk mengevaluasi hal yang terkait dengan pengembangan bahan ajar berdasarkan hasil uji coba di lapangan.

Jenis data dalam penelitian ini berupa data kualitatif dan kuantitatif. Data kualitatif berupa saran atau komentar dari validator. Data kuantitatif diperoleh dari skor penilaian validator terhadap buku pengayaan, skor penilaian kepraktisan buku pengayaan oleh guru dan siswa, dan hasil penilaian keefektifan berupa hasil tes kemampuan pemecahan masalah siswa.

Instrumen yang digunakan untuk mengumpulkan data pada penelitian ini dibedakan dalam 3 kategori, yaitu: (1) instrumen kevalidan, terdiri atas lembar validasi bahan ajar berupa buku pengayaan dan lembar validasi instrumen penilaian keeektifan; (2) instrumen kepraktisan berupa lembar penilaian kepraktisan buku pengayaan oleh guru dan siswa; dan (3) instrumen keefektifan bahan ajar berupa tes kemampuan pemecahan masalah siswa.

Penilaian kevalidan ditinjau dari desain buku dan isi buku. Pada desain buku, komponen yang dinilai berupa desain sampul buku dan desain isi buku. Pada isi buku, komponen yang dinilai berupa kelayakan isi, kelayakan penyajian, kelayakan kebahasaan, dan karakteristik faded examples. Skor penilaian terdiri dari lima kriteria yaitu: sangat baik (skor 5), baik (skor 4), cukup baik (skor 3), kurang baik (skor 2), dan tidak baik (skor 1). Simpulan penilaian terdiri dari tiga kategori pilihan yaitu layak digunakan tanpa revisi, layak digunakan dengan revisi dan tidak layak digunakan; serta komentar/saran dari validator.

Penilaian kepraktisan oleh guru dan siswa masing-masing ditinjau dari empat komponen yaitu: desain buku, penyajian materi, penggunaan buku, dan kesesuaian penyusunan bahan ajar berdasarkan teknik faded examples. Terdapat 15 butir pernyataan yang dapat digunakan oleh guru dan siswa untuk mengukur kepraktisan bahan ajar. Skor penilaian kepraktisan terdiri dari lima kriteria yaitu: sangat setuju (skor 4), setuju (skor 3 ), tidak setuju (skor 2), dan sangat tidak setuju (skor 1).

Penilaian keefektifan dilaksanakan setelah siswa mengikuti proses pembelajaran. Setiap siswa diberikan soal tes kemampuan pemecahan masalah dan mengerjakan soal secara mandiri. Hasil tes tersebut dinyatakan dalam skala 0-100.

Analisis data dalam penelitian ini bertujuan untuk mengolah data penelitian sehingga mengarah pada simpulan yang mendeskripsikan dan menjawab pertanyaan penelitian. Analisis data dilakukan secara berkelanjutan terutama untuk data yang bersifat kualitatif. Data-data ini berisi informasi untuk merevisi prototip bahan ajar yang dikembangkan sehingga mencapai kualitas valid, praktis dan efektif. Data yang diperoleh meliputi data-data kuantitatif dari lembar validasi bahan ajar, lembar validasi 
instrumen penilaian, lembar penilaian kepraktisan bahan ajar oleh guru dan siswa, dan hasil tes pemecahan masalah siswa.

Penilaian kelayakan bahan ajar diklasifikasikan dalam lima kriteria dengan mengacu pada kriteria penilaian skala lima oleh (Widoyoko, 2013, p. 238).

Kevalidan produk dinilai berdasarkan lembar validasi yang diisi oleh ahli. Selanjutnya, data kualitatif berupa saran digunakan sebagai bahan perbaikan produk. Penilaian secara kuantitatif dilakukan dengan mengonversi skor dengan klasifikasi skala lima. Klasifikasi penilaian kevalidan bahan ajar dapat dilihat pada Tabel 1 .

Tabel 1. Klasifikasi Penilaian Kevalidan Bahan Ajar

\begin{tabular}{cc}
\hline Interval Rerata Skor & Kualitas \\
\hline $\bar{x}>2,6$ & Valid \\
$\bar{x} \leq 2,6$ & Tidak Valid \\
\hline
\end{tabular}

Kualitas bahan ajar dianggap valid dan layak untuk dikembangkan jika rata-rata hasil penilaian kevalidan bahan ajar yang diberikan oleh kedua validator terkategori valid.

Analisis data kevalidan instrumen penilaian kemampuan pemecahan masalah dilakukan dengan langkah-langkah sebagai berikut: (1) mengecek kesimpulan pada lembar validasi instrumen penilaian kemampuan pemecahan masalah yang telah diisi oleh validator, (2) merevisi maupun mengganti butir soal yang belum berada pada kriteria "Baik", (3) instrumen penilaian kemampuan pemecahan masalah dinyatakan valid apabila seluruh butir soal berada pada kriteria "Baik".

Langkah-langkah yang digunakan untuk memberikan kriteria kepraktisan bahan ajar adalah sebagai berikut: (1) merekap total skor dari lembar kepraktisan yang telah diisi oleh guru dan siswa, (2) menghitung rata-rata skor dari lembar kepraktisan yang telah diisi oleh guru dan siswa, (3) hasil yang diperoleh pada poin (2) kemudian dirujuk pada Tabel 2.

Tabel 2. Klasifikasi Penilaian Kualitas Kepraktisan

\begin{tabular}{cc}
\hline Interval Rerata Skor & Klasifikasi \\
\hline$\overline{\mathrm{x}}>2,6$ & Praktis \\
\hline$\overline{\mathrm{x}} \leq 2,6$ & Tidak Praktis \\
\hline $\bar{x}=$ rerata skor &
\end{tabular}

$\bar{x}=$ rerata skor

Kualitas bahan ajar dianggap memenuhi kualitas kepraktisan apabila penilaian kepraktisan dari guru dan siswa terkategori praktis.
Penilaian keefektifan bahan ajar dilakukan dengan menggunakan soal-soal pemecahan masalah yang disesuaikan dengan materi pada bahan ajar. Adapun poin-poin penilaian mencakup proses pemecahan masalah siswa yang terlihat dari kemampuan siswa dalam menerapkan konsep yang telah dipelajari, mengaplikasikan strategi pemecahan masalah, kemampuan siswa dalam menjabarkan penyelesaian masalah, akurasi, serta kemampuan siswa dalam menarik kesimpulan. Selanjutnya hasil tes kemampuan pemecahan masalah tersebut dikonversikan ke dalam nilai dari skala 0 sampai 100 . Bahan ajar yang dikembangkan dikatakan sangat efektif apabila ketuntasan belajar seluruh siswa lebih dari $80 \%$ (Morrison, Ross, Kemp, \& Kalman, 2010, p. 289). Adapun ketuntasan belajar siswa pada pengayaan materi trigonometri yang ditetapkan disesuaikan dengan nilai KKM yang ditetapkan di sekolah untuk pelajara matematika yaitu 75 .

\section{HASIL DAN PEMBAHASAN}

Bahan ajar yang dikembangkan dalam penelitian ini terdiri dari buku guru dan buku siswa untuk materi pengayaan yang disesuaikan dengan materi trigonometri SMA pada Kurikulum 2013. Materi trigonometri yang dipilih adalah materi kelas $\mathrm{X}$ yang dikembangkan sebagai materi pengayaan.

Dalam penelitian ini, buku guru memiliki karakteristik yang hampir sama dengan buku siswa. Perbedaan karakteristik pada buku guru dan buku siswa hanya terletak pada kunci jawaban yang hanya disediakan pada buku guru untuk setiap langkah penyelesaian dalam rangkaian paket faded examples.

Karakteristik bahan ajar yang dikembangkan dalam penelitian ini meliputi (1)Terdapat peta pengembangan kompetensi dan peta materi pembelajaran di awal bab untuk memberikan gambaran tentang keterkaitan antara materi yang telah dipelajari oleh siswa dengan materi yang akan dipelajari siswa; (2) Terdapat apersepsi di awal bab yang bertujuan untuk mengaktifkan prior knowledge siswa terkait materi yang akan dipelajari; (3) Berisi soal-soal pemecahan masalah yang dikemas dalam bentuk paket faded examples; (4)Terdapat ciri-ciri faded example, yaitu sesuai dengan kemampuan kognitif awal siswa (intrinsic cognitive load), tingkat kesulitan bertahap (intrinsic cognitive load), menghindari redundant dan split-attention information (extraneous cognitive load), ada kunci jawaban (germane cognitive load), serta terdapat 
penjelasan tiap langkah (germane cognitive load).

Setelah produk awal bahan ajar disusun berdasarkan saran dan masukan dari dosen pembimbing, produk tersebut divalidasi oleh dua ahli dalam matematika khususnya pada bidang trigonometri.

Tabel 3. Hasil Rekapitulasi Analisis Kevalidan Produk

\begin{tabular}{lc}
\hline \multicolumn{1}{c}{ Aspek } & $\begin{array}{c}\text { Rata-rata } \\
\text { penilaian }\end{array}$ \\
\hline Desain sampul buku & 4,67 \\
Desain isi buku & 4,67 \\
Kesesuaian isi materi dengan SK, KD, & 4,83 \\
dan indikator pengayaan & 4,67 \\
Keakuratan materi & 4,67 \\
Materi pendukung pembelajaran & 4,75 \\
Teknik penyajian & 4,50 \\
Pendukung penyajian & 4,50 \\
Ketepatan kalimat & 5,00 \\
Komunikatif & 4,80 \\
Penerapan Faded Examples dalam & $\mathbf{4 , 6 8}$ \\
Bahan Ajar & Rangat \\
\hline \multicolumn{2}{c}{ Klasifikasi } \\
\end{tabular}

Berdasarkan penilaian tersebut, rata- rata skor total dari penilaian adalah 4.68 dengan klasifikasi secara kuantitatif adalah sangat baik. Dengan demikian, kualitas produk pengembangan berupa buku pengayaan trigonometri SMA IPA menggunakan faded examples dianggap valid dan layak sebagai bahan ajar karena memiliki klasifikasi sangat baik atau $\bar{x}>$ 4,1 yaitu 4,68.

Penilaian kualitas kepraktisan dalam tahap ini berdasarkan penilaian guru pada lembar kepraktisan untuk guru dan penilaian siswa berdasarkan lembar kepraktisan untuk siswa. Penilaian yang diberikan oleh guru dapat dijabarkan dalam Tabel 4.

Tabel 4. Klasifikasi Hasil Penilaian Guru terhadap Buku Pengayaan

\begin{tabular}{ll}
\hline Aspek Penilaian & Rata-rata nilai \\
\hline Tampilan & 4,7 \\
Penyajian materi & 4,7 \\
Kemudahan penggunaan & 4,67 \\
\hline Nilai rata-rata & 4,69 \\
Klasifikasi & Sangat Praktis \\
\hline
\end{tabular}

Berdasarkan Tabel 4 diketahui bahwa kualitas bahan ajar pengayaan menurut penilaian guru kelas X SMAN 5 Mataram dikatakan praktis karena berada pada kriteria "sangat praktis" dengan rata-rata nilai 4,69.
Setelah melakukan analisis data kepraktisan bahan ajar yang digunakan, langkah selanjutnya adalah menganalisis kemampuan pemecahan masalah siswa. Kemampuan pemecahan masalah siswa dianalisis berdasarkan hasil tes kemampuan pemecahan masalah yang telah dikonversi ke dalam skala 1 sampai 100. Dari hasil yang diperoleh, kemampuan pemecahan masalah selanjutnya diklasifikasikan secara kualitatif dengan melihat persentase ketuntasan belajar siswa. Hasil klasifikasi dapat dilihat pada Tabel 5.

Tabel 5. Klasifikasi Kualitatif Hasil Tes Pemecahan Masalah Siswa

\begin{tabular}{cccc}
\hline Skor & Klasifikasi & $\begin{array}{c}\text { Persentase } \\
\text { Kelas X } \\
\text { Pengayaan1 }\end{array}$ & $\begin{array}{c}\text { Persentase } \\
\text { Kelas X } \\
\text { Pengayaan 2 }\end{array}$ \\
\hline $60<\mathrm{t} \leq 100$ & Baik & $95,2 \%$ & $100 \%$ \\
$40<\mathrm{t} \leq 60$ & Cukup baik & $4,8 \%$ & $0 \%$ \\
$0<\mathrm{t} \leq 40$ & Tidak baik & $0 \%$ & $0 \%$ \\
\hline \multicolumn{2}{c}{ Klasifikasi } & \multicolumn{2}{c}{ Sangat baik } \\
\hline
\end{tabular}

Berdasarkan hasil tes kemampuan pemecahan masalah siswa kelas $\mathrm{X}$ pengayaan 1 dari 25 siswa diketahui bahwa sekitar 23 siswa siswa mendapat klasifikasi baik, 2 siswa atau 4,8\% siswa mendapat klasifikasi cukup baik, dan tidak ada siswa atau $0 \%$ siswa mendapat klasifikasi tidak baik maupun sangat tidak baik. Pada hasil tes prestasi belajar matematika siswa kelas $\mathrm{X}$ pengayaan 2 juga diketahui bahwa dari 25 siswa, sekitar 25 siswa mendapat klasifikasi baik dan tidak ada siswa atau 0\% siswa mendapat klasifikasi cukup baik, tidak baik maupun sangat tidak baik. Oleh karena nilai rata-rata kelas X pengayaan 1 dan $X$ pengayaan 2 yang berada pada klasifikasi "sangat baik" maka bahan ajar yang digunakan efektif ditinjau dari kemampuan pemecahan masalah siswa pada materi trigonometri pengayaan.

Tercapainya kriteria kevalidan, kepraktisan, dan keefektifan bahan ajar dipengaruhi oleh adanya kegiatan revisi produk yang telah dilaksanakan oleh peneliti. Revisi ini dibagi dalam dua bagian yaitu: yaitu revisi sebelum uji coba dan revisi setelah uji coba.

Sebelum uji coba dilakukan beberapa kali revisi berdasarkan saran dari dosen pembimbing seperti perbaikan format buku pengayaan sehingga buku pengayaan yang dikembangkan dapat mencerminkan karakteristik dari cognitive load theory sebagai dasar teori dari teknik faded examples. Di awal bab juga ditambahkan peta materi yang berfungsi untuk memudahkan siswa mengaitkan antara materi sebelumnya dengan 
Jurnal Riset Pendidikan Matematika, 5 (1), 2018 - 79

Hanifa Prahastami Pambayun, Endah Retnowati

Revisi beberapa kalimat dan penjelasan terkait materi sehingga dapat meminimalisir extraneous cognitive load siswa. Selanjutnya, format pada langkah penyelesaian juga diperjelas dengan menggunakan tabel sehingga dapat mengurangi terjadinya split attention.

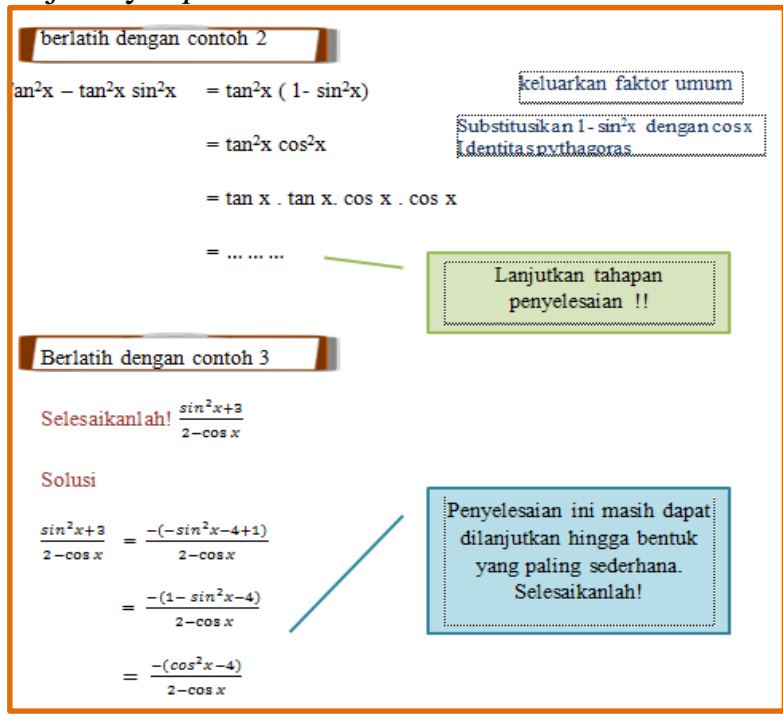

Gambar 1. Format pada Langkah Penyelesaian Sebelum Revisi

\begin{tabular}{l}
\hline \multicolumn{1}{|c|}{ Faded examples A1 } \\
$\begin{array}{l}\text { Pelajari empat contoh berikut dengan melengkapi langkah-langkah yang diberikan! } \\
\text { a. } \sin \theta+\operatorname{ctg} \theta \cos \theta \\
\text { Solusi }\end{array}$ \\
\begin{tabular}{|l|l|}
\hline \multicolumn{1}{|c|}{ Langkah-langkah } & \multicolumn{1}{|c|}{ Uraian Penyelesaian } \\
\hline $\begin{array}{l}\text { Langkah } 1 \\
\text { gunakan identitas trigonometri } \\
\operatorname{ctg} \theta=\left(\frac{\cos \theta}{\sin \theta}\right)\end{array}$ & $\sin \theta+\operatorname{ctg} \theta \cos \theta=\sin \theta+\left(\frac{\cos \theta}{\sin \theta}\right) \cos \theta$ \\
\hline $\begin{array}{l}\text { Langkah } 2 \\
\text { samakan penyebut ruas kanan } \\
\operatorname{sehingga~menjadi~} \sin \theta\end{array}$ & $\Leftrightarrow \sin \theta+\operatorname{ctg} \theta \cos \theta=\frac{\sin ^{2} \theta+\cos ^{2} \theta}{\sin \theta}$ \\
\hline $\begin{array}{l}\text { Langkah } 3 \\
\text { gunakan identitas trigonometri } \\
\sin { }^{2} \theta+\cos ^{2} \theta=1\end{array}$ & $\Leftrightarrow \sin \theta+\operatorname{ctg} \theta \cos \theta=\frac{1}{\sin \theta}$ \\
\hline $\begin{array}{l}\frac{\text { Langkah } 4}{\text { gunakan identitas trigonometri }} \\
\frac{1}{\sin \theta}=\csc \theta\end{array}$ & $\Leftrightarrow \sin \theta+\operatorname{ctg} \theta \cos \theta=\csc \theta$ \\
\hline
\end{tabular}
\end{tabular}

Gambar 2. Format pada Langkah Penyelesaian Setelah Revisi

Sebelum revisi hanya ada paket backward fading. Setelah direvisi berdasarkan saran dosen pembimbing, pada buku pengayaan ditambahkan paket faded examples yaitu forward fading atau menghapus langkah penyelesaian yang dimulai dari langkah pertama hingga siswa mengerjakan sendiri soal tanpa diberikan langkah penyelesaian. Paket backward fading di dalam buku terdiri dari 56 soal, sedangkan paket backward fading terdiri atas 63 soal trigonometri.

Setelah dihasilkan produk yang telah disetujui oleh dosen pembimbing, langkah selanjutnya adalah memvalidasi produk dan meminta saran dan pendapat dari dosen ahli selaku validator. Pada tahap ini diperoleh beberapa saran yang digunakan sebagai bahan untuk memperbaiki produk. Salah satu revisi yang dilakukan adalah adanya perubahan apersepsi untuk nilai trigonometri di tiap kuadran. Dengan dilakukan perubahan apersepsi ini diharapkan siswa dapat mengkonstruk kembali prior knowledge yang telah dimiliki.

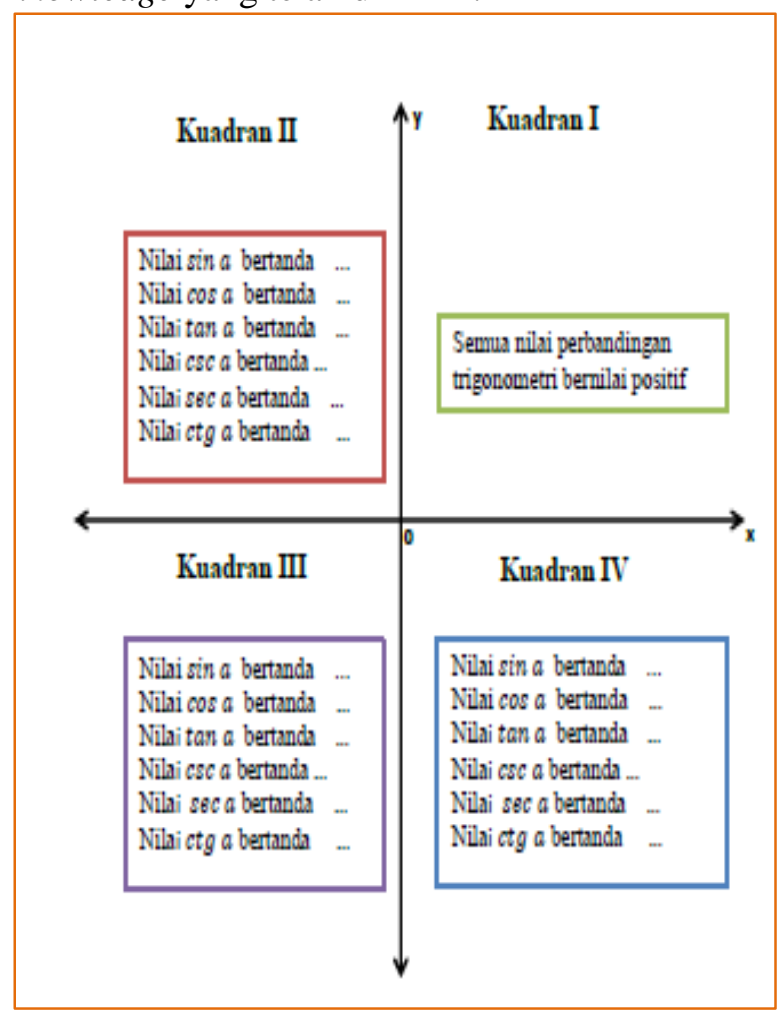

Gambar 3. Apersepsi Sebelum Revisi

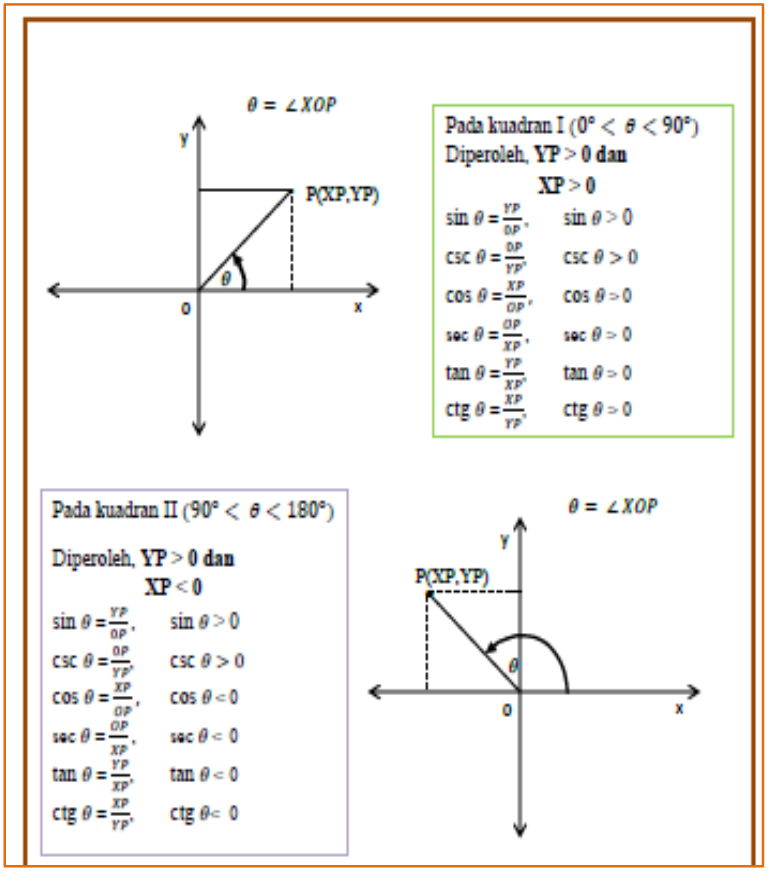

Gambar 4. Apersepsi Setelah Revisi 
Selain itu juga dilakukan revisi beberapa soal faded examples beserta langkah penyelesaiannya. Revisi dilakukan dengan mengganti dua butir soal faded examples dan mengganti langkah penyelesaian sehingga lebih mudah dipahami.

Tahapan selanjutnya yaitu proses uji coba produk. Produk berupa bahan ajar pengayaan diujicobakan untuk mengukur kepraktisan dan keefektifan produk. Setelah uji coba dilaksanakan, dilakukan revisi akhir berdasarkan saran dari guru matematika yang mengajar di kelas uji coba dan saran dari siswa yang diperoleh berdasarkan lembar kepraktisan dan selama melakukan pembelajaran. Revisi setelah ujicoba seperti menyederhanakan langkah penyelesaian dalam paket faded examples.

\section{SIMPULAN}

Berdasarkan Berdasarkan uraian terkait hasil dan pembahasan, diperoleh kesimpulan yaitu: (1) Teknik faded examples dalam pengembangan bahan ajar pengayaan untuk materi trigonometri SMA IPA dikembangkan sesuai dengan prinsip-prinsip pada cognitive load theory dan terdapat paket faded examples dengan jenis backward dan forward fading, (2) berdasarkan penilaian para ahli tersebut, produk dan instrumen dinyatakan valid atau layak untuk digunakan, (3) berdasarkan hasil yang diperoleh, kualitas produk pengembangan berupa buku pengayaan yang terdiri dari buku guru dan buku siswa dinyatakan praktis untuk digunakan dalam pembelajaran, dan (4) bahan ajar yang dikembangkan dinyatakan efektif digunakan dalam pembelajaran yang dilihat dari penilaian pada aspek keefektifan berupa tes kemampuan pemecahan masalah siswa.

Beberapa saran untuk pemanfaatan bahan ajar pengayaan trigonometri SMA menggunakan teknik faded examples yaitu: (1)produk dari pengembangan ini hendaknya dapat digunakan dalam pembelajaran matematika khususnya pada materi pengayaan trigonometri, (2) Perlunya pengembangan materi yang lebih mendetail serta bervariasi sehingga dapat meningkatkan kualitas bahan ajar, (3) Perlu adanya tindak lanjut dari peneliti lain untuk menyempurnakan produk yang dihasilkan pada penelitian ini.

\section{DAFTAR PUSTAKA}

Ahmad, H. (2015). Peningkatan kemampuan penalaran matematika materi trigonometri melalui penerapan model pembelajaran discovery learning dengan pendekatan saintifik pada kelas X SMA Negeri 11

Makasar. Jurnal Daya Matematis, 3(3), 299-307.

Clark, R. C., Nguyen, F., \& Sweller, J. (2011). Efficiency in learning: Evidence-based guidelines to manage cognitive load. John Wiley \& Sons.

Creswell, J. (2015). Education Research, Planing, conducting, and evaluating quantitative and qualitative. New York: Peason Education, Inc.

Departemen Pendidikan Nasional. (2008). Panduan penyelenggaraan pembelajaran pengayaan. Jakarta: Departemen Pendidikan Nasional.

Fennema, E., \& Romberg, T. A. (1999). Mathematics classrooms that promote understanding. Marwah, NJ: Lawrence Erlbaum Associates Mahwah, NJ.

Kalyuga, S. (2008). Relative effectiveness of animated and static diagrams: An effect of learner prior knowledge. Computers in Human Behavior, 24(3), 852-861. https://doi.org/10.1016/J.CHB.2007.02.01 8

Khomsiatun, S., \& Retnawati, H. (2015). Pengembangan perangkat pembelajaran dengan penemuan terbimbing untuk meningkatkan kemampuan pemecahan masalah. Jurnal Riset Pendidikan Matematika, 2(1), 92. https://doi.org/10.21831/jrpm.v2i1.7153

Majid, A. (2008). Perencanaan pembelajaran mengembangkan standar kompetensi guru. Bandung: PT Remaja Rosdakarya.

Morrison, G. R., Ross, S. M., Kemp, J. E., \& Kalman, H. (2010). Designing effective instruction. New York, N.Y.: John Wiley \& Sons.

National Council of Teacher Mathematics. (2000). Prinsiples and standards for school mathematics. Reston, VA: NCTM.

Newby, T. J., Lehman, J., Russel, J., \& Stepich, D. A. (2000). Instructional technology for teaching and learning: designing instruction, integrating computers, and using media. New Jersey: Merrill.

Nitko, A. J., \& Brookhart, S. M. (2011). Educational assessment of students. New Jersey: Pearson/Allyn \& Bacon.

Plomp, T. (2013). Educational design research: An introduction. In $\mathrm{N}$. Nieveen \& $\mathrm{T}$. 


\section{Jurnal Riset Pendidikan Matematika, 5 (1), 2018 - 81}

Hanifa Prahastami Pambayun, Endah Retnowati

Plomp (Eds.), Educational design research - Part A: An introduction (pp. 10-51). Enschede: Netherlands Institute for Curriculum Development (SLO). Retrieved from http://international.slo.nl/publications/edr/

Plomp, T., \& Nieveen, N. (2007). An introduction to educational design research. In Proceedings of the seminar conducted at the East China Normal University, Shanghai (PR China) (pp. 2326).

Prastowo, A. (2011). Panduan kreatif membuat bahan ajar inovatif. Jogjakarta: DIVA Press.

Renkl, A., Atkinson, R. K., \& Große, C. S.
(2004). How fading worked solution steps works - A cognitive load perspective. Instructional Science, 32(1/2), 59-82. https://doi.org/10.1023/B:TRUC.0000021 815.74806.f6

Sweller, J., Ayres, P., \& Kalyuga, S. (2011). Cognitive load theory. New York, N.Y.: Springer.

Widodo, C. S., \& Jasmadi, J. (2008). Panduan menyusun bahan ajar berbasis kompetensi. Jakarta: Elex Media Komputindo.

Widoyoko, S. E. P. (2013). Evaluasi program pembelajaran: panduan praktis bagi pendidik dan calon pendidik. Yogyakarta: Pustaka Pelajar. https://doi.org/2013 